\title{
Peptide Gelators to Template Inorganic Nanoparticle Formation
}

\author{
Ottavia Bellotto ${ }^{1}$, Maria C. Cringoli ${ }^{1,2}$ D, Siglinda Perathoner ${ }^{3,4}$, Paolo Fornasiero 1,2,5 $^{(D)}$ \\ and Silvia Marchesan 1,2,*(D)
}

1 Chemical and Pharmaceutical Sciences Department, University of Trieste, 34127 Trieste, Italy; ottavia.bellotto@phd.units.it (O.B.); mcringoli@units.it (M.C.C.); pfornasiero@units.it (P.F.)

2 INSTM, Unit of Trieste, 34127 Trieste, Italy

3 Dipartimento di Scienze Chimiche, Biologiche, Farmaceutiche e Ambientali, University of Messina, 98168 Messina, Italy; siglinda.perathon@unime.it

4 INSTM, Unit of Messina, 98168 Messina, Italy

5 Istituto di Chimica dei Composti Organometallici, Consiglio Nazionale delle Ricerche (ICCOM-CNR), 34127 Trieste, Italy

* Correspondence: smarchesan@units.it; Tel.: +39-040-5583923

\section{check for} updates

Citation: Bellotto, O.; Cringoli, M.C.; Perathoner, S.; Fornasiero, P.;

Marchesan, S. Peptide Gelators to

Template Inorganic Nanoparticle

Formation. Gels 2021, 7, 14. https:// doi.org/10.3390/gels7010014

Received: 3 January 2021

Accepted: 30 January 2021

Published: 2 February 2021

Publisher's Note: MDPI stays neutral with regard to jurisdictional claims in published maps and institutional affiliations.

Copyright: (c) 2021 by the authors. Licensee MDPI, Basel, Switzerland. This article is an open access article distributed under the terms and conditions of the Creative Commons Attribution (CC BY) license (https:/ / creativecommons.org/licenses/by/ $4.0 /)$.

\begin{abstract}
The use of peptides to template inorganic nanoparticle formation has attracted great interest as a green route to advance structures with innovative physicochemical properties for a variety of applications that range from biomedicine and sensing, to catalysis. In particular, short-peptide gelators offer the advantage of providing dynamic supramolecular environments for the templating effect on the formation of inorganic nanoparticles directly in the resulting gels, and ideally without using further reductants or chemical reagents. This mini-review describes the recent progress in the field to outline future research directions towards dynamic functional materials that exploit the synergy between supramolecular chemistry, nanoscience, and the interface between organic and inorganic components for advanced performance.
\end{abstract}

Keywords: peptides; gels; inorganic nanoparticles; nanowires; nanotubes; nanostructures; metal; metal oxides; self-assembly

\section{Introduction}

Supramolecular gels composed of peptides have attracted great interest in recent years across multidisciplinary research communities for a variety of reasons [1]. Firstly, peptides, especially short ones, can readily be prepared by well-established solid-phase methods, also for ease of purification [2]. Secondly, they allow greater chemical diversity, relative to other classes of compounds, which has been further expanded by the introduction of a large variety of non-natural amino acids [3,4]. Thirdly, as the complex function of proteins can be pinned to specific sets of peptide sequences, it has been shown that peptides can encode for at least some of protein functionalities [5]. Fourth, when a function is encoded within a supramolecular system, it is possible to envisage its on/off switching by means of assembly/disassembly cycles, a convenient feature especially for biomedical applications [6]. Finally, peptides are inherently biodegradable and biocompatible, thus facilitating the use of green solvents, such as water, for their final systems that will not excessively persist in the environment; this is particularly relevant for the development of alternatives to traditional materials used in electronics [7].

However, peptide gels have also their limitations, and for this reason research has been very active on the development of composite or hybrid gels with additional chemical components to enhance their properties [8,9]. Examples show a wide range of chemical diversity, which includes synthetic polymers [10,11], polysaccharides [12] and nucleic acids [13], carbon nanostructures [14], polyoxometallates [15], metal-organic cages [16], and more. A particular class of additional components that deserves a separate discussion is inorganic nanoparticles (NPs). Several reviews have recently appeared on how to guide their 
formation using ionizing radiation [17], hydrothermal routes [18], microemulsions [19], microfluidics [20], aerogels [21], air/liquid interfaces [22], polymers [23], cyclodextrins [24] and host-guest interactions [25], ligands [26], and proteins [27]. In particular, it is wellknown that inorganic nanoparticles do exist in nature [28], and their biosynthesis has been a source of inspiration for chemists for a long time [29] to develop green routes with fine control over their shape and size (Figure 1). This is particularly relevant for applications, for instance to achieve optimal performance of nanostructured catalysts [30], for the transition towards clean energy production and storage [31].

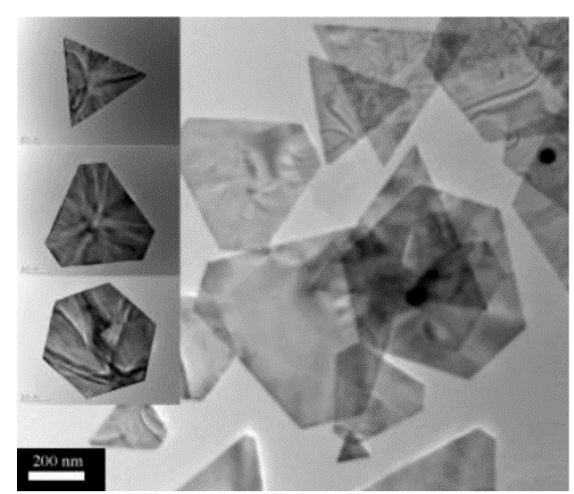

(a)

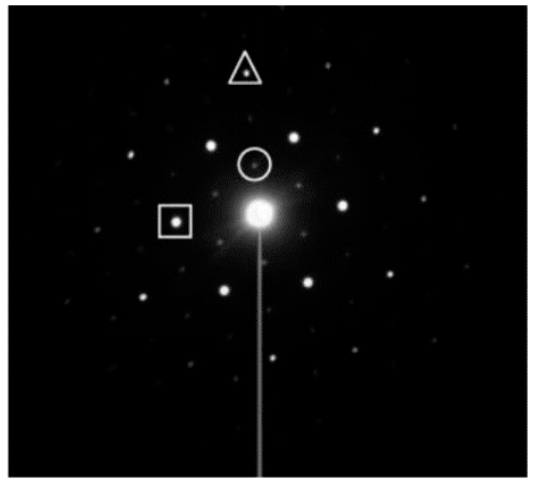

(b)

Figure 1. (a) TEM images of gold nanoplates obtained from the reduction of chloroaurate using seaweed extract. (b) The selective area electron diffraction (SAED) pattern of a triangular nanoplate. The strongest spots (square) could be assigned to the $\{220\}$ reflections, the outer spots (triangle) with weaker intensity could be indexed to the $\{422\}$ reflections, and the inner spots (circle) with the weakest intensity correspond to the formally forbidden $1 / 3\{422\}$ reflections. Adapted with permission from [32]. Copyright (c) 2021, American Chemical Society.

The process of biomineralization starts when the mineral inorganic precursors and specific organic biomolecules come into contact; often, the biomolecules that come into play are proteins [33]. However, there is large diversity (and lack of homology) in the amino acid sequence of the proteins involved in the process, when they are known [33]. Peptide sequences capable of templating inorganic NP formation typically display N-/O/S-donor groups for metal coordination (Figure 2), although the relationship between peptide sequence and the templating effect has not yet been identified [34].

The general understanding is that peptides can bind to nuclei or metal nanoclusters and create a reducing environment that promotes metal ion reductions to metal NPs [35]. Among the various functional groups involved in the process, hydroxyl groups (e.g., found in Tyr, Ser, or DOPA [36] amino acids) have recently gained attention, as they are often found in other biomolecules, i.e., sugars and polyphenols, which act as reducing agents in the biosynthesis of metal nanoparticles [37]. Amines (e.g., from Lys) often exert a role as capping agents, as one of the steps in a mechanism whose complexity has not yet been completely clarified [38]. Cys-thiols are widely exploited for the coordination of gold (and silver) to favor the initial steps of nucleation. However, it should be kept in mind that a variety of factors and processes clearly come into play to define the resulting nanomaterial, including thermodynamic aspects, such as the rate of nucleation relative to that of crystal growth, and phenomena that include Ostwald ripening and stacking faults [39].

In other strategies, photoreduction is used, and several examples have been described for the in situ formation for instance of silver NPs [40-42]. Additionally, the photoreduction of gold can be performed on the surface of peptides as capping agents to stabilize the resulting NPs, for application in the biochemical field, such as siRNA vectors for oncotherapy [43]. Either strategy is particularly attractive as it permits to avoid the use of polluting chemical reagents or harsh reaction conditions. 
Therefore, the combination of peptide gelling ability with their templating effects for inorganic NP formation is particularly attractive as a green and easy way to achieve composite or hybrid organic-inorganic nanostructured materials [44]. Furthermore, peptide gels can also provide colloidal stability to the NPs, as well as a convenient method for their physical embedment in space, and their controlled delivery over time [44]. There are already quite a few reports of peptide gels used to template inorganic NP formation as discussed in detail further below. This review will not focus on systems whereby NP formation is chemically driven by the addition of reductants or other reagents besides the gelator, nor on peptide gelation in the presence of pre-formed NPs, a topic that has already been reviewed elsewhere [45].

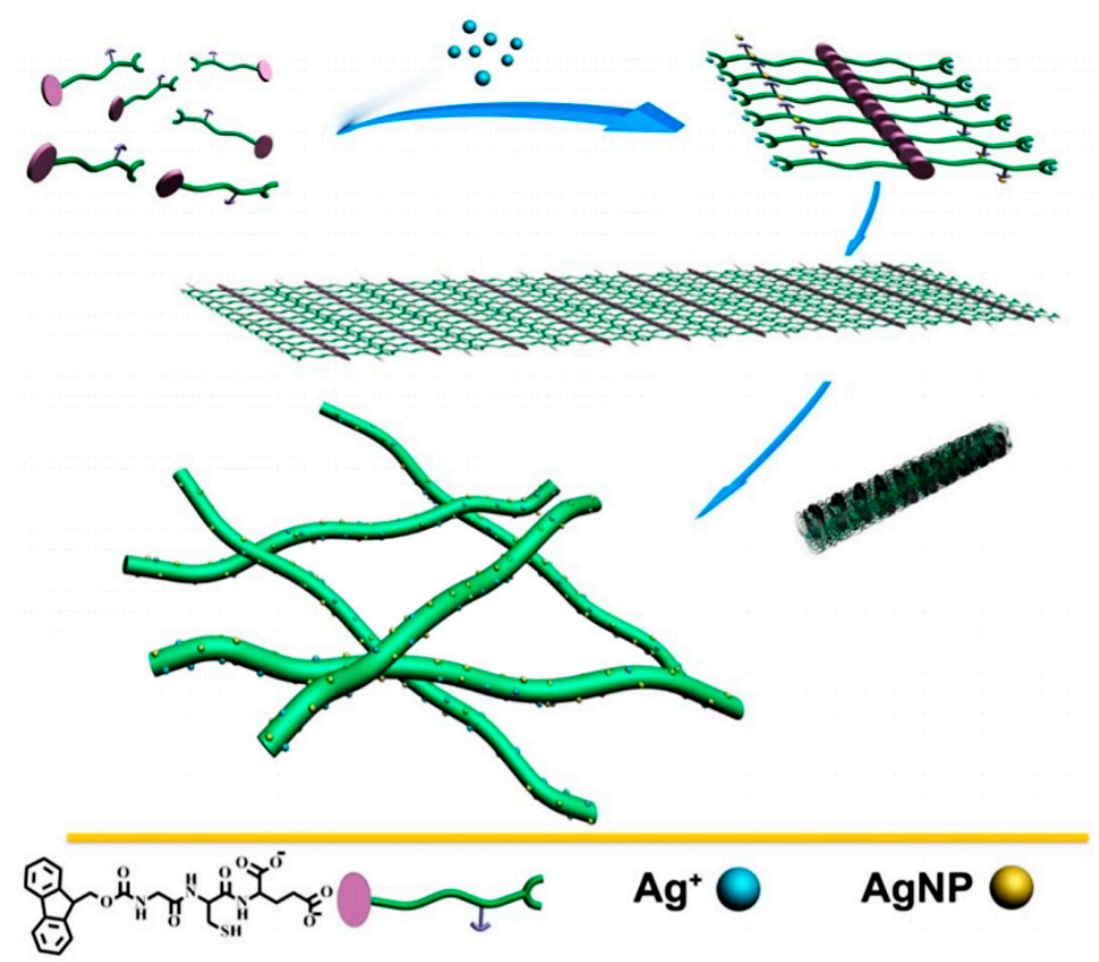

Figure 2. The templating effect of a tripeptide gelator bearing carboxylates and a thiol moiety for $\mathrm{Ag}^{+}$coordination results in the formation of silver nanoparticles (AgNP) onto the gelling nanofibers that arise from the peptide stacks. Reprinted with permission from [46]. Copyright (C 2021, American Chemical Society.

\section{Inorganic Nanostructure-Templating Effects by Peptides}

The conjugation of peptides and metallic NPs, especially gold and magnetic iron oxide NPs, is of particular interest in nanomedicine for the targeting of sub-cellular biological structures, such as proteins or genes, as has been already reviewed [47]. Silica nanostructures are also promising especially in light of their chemically rather inert nature, inability to conduct electrons and highly transparent nature, and the process of biomineralization has been a source of inspiration to use proteins to direct silica NP formation [48]. Elongated nanostructures have also attracted attention thanks to their inherent chemical, magnetic, electrical, and optical anisotropy that find application especially in sensing [49], but also in drug delivery [50]. Similarly, the ordered arrangement in space at the nanoscale of metal NPs, such as silver NPs, can be advantageous to control their plasmonic properties for surface enhanced Raman spectroscopy (SERS) [51].

Peptides that bind on NP surfaces are interesting because they can also be used for biological targeting and may play a role in determining NP biodegradation [52]. Early studies identified over 30 peptide sequences able to bind cobalt ions, and nearly 20 that bound silver ions by using phage-display and PCR methods [53]. The ions were reduced 
in situ into spherical or polyhedral-shaped nanoparticles of average diameters ranging from ca. 50 to $100 \mathrm{~nm}$, but no clear rationale was found that could relate the amino acid sequence with nanoparticle formation, other than the presence of recurrent amino acids, such as cysteine (Cys), histidine (His), glutamic acid (Glu), isoleucine (Ile), tryptophan (Trp), and tyrosine (Tyr) [53]. However, no gel was formed.

In particular, Tyr redox activity on gold ions was already well known, as it was noted that alkylated-Tyr served as phase transfer, reducing and capping agent for the formation of gold-NPs at liquid-liquid or liquid-air interfaces [54]. Cys was also a well-known ligand for silver and gold ions. Several Cys-bearing peptide sequences have been described for their ability to promote gold nanocluster formation [55], as well as gold NPs as described further below. Additionally, the dimerized form of cysteine has been used to promote selenium (Se) NP formation, exploiting sulfur affinity for Se, although ascorbic acid as reducing agent was also needed [56]. Furthermore, the use of peptide ligands can be advantageous to induce a chiral templating effect; to this end, the tripeptide Tyr-Tyr-Cys was recently used as a ligand to promote the formation of chiral cobalt oxide NPs, and the use of $\mathrm{N}$ - or C-terminally protected analogs demonstrated an important role played also by the peptide carboxylate in the interactions with the metal [57]. Analogously, Trp-bearing dipeptide amphiphiles were used for the in situ formation of gold NPs, whereby different morphologies could be attained based on the specific porosity and the templating effect of the different hydrogelators [58].

As another strategy, also simple hydrophobic tripeptide gelators were shown to be prone to biomineralization, through the deposition in situ of luminescent cadmium sulfide (CdS) NPs, which demonstrated altered optoelectronic properties with a blue-shift, once they were anchored onto the fibrillary network of the resulting hydrogel [59]. However, it should be noted that in this case the peptide fibers did not catalyze NP formation, which was performed by using cadmium nitrate, sodium sulfide and cysteine [59]. Table 1 reports key examples of peptide gelators that were used to promote the in situ formation of inorganic NPs, and further below specific examples are described based on the nanostructure morphology attained and the metal used, which is relevant for the envisaged applications as discussed in each section.

\subsection{Nanoparticles \\ 2.1.1. Gold $(\mathrm{Au})$}

Gold nanoparticles are well-known for their physicochemical properties that find applications in a variety of fields. Gold NPs have been widely researched for their use in catalysis and beyond [71]. Gold is notable for its good biocompatibility and its surface plasmon oscillations are advantageous for labelling, imaging, and sensing [72]. Obviously, these properties find interesting applications in the biomedical field, both in the diagnosis and therapy of cancer [73], as well as in their combination in the modern field of theranostics [74]. It is, thus, clear that their combination with (bioactive) peptides is particularly attractive to develop biomaterials [75].

A series of peptide amphiphile gelators based on $N, N, N$-trimethylammonium Phe successfully templated gold NPs in various shapes and sizes, with preference over octahedral geometry upon optimization of experimental conditions [66]. Variations including Trp as reducing agent for $\mathrm{Au}^{3+}$ were also effective, and allowed to control the gold nanomorphology [58]. Other studies on dipeptide amphiphiles demonstrated that Trp was actually not necessary for Au NP formation; also aromatic N-methylation on Trp-bearing amphiphiles or amphiphiles based on Phe instead of Trp, allowed for the templating of spherical Au NPs with good size-control on the surface of nanofibers, showing that hydrophobic and confinement effects were more important [64]. Interestingly, NP-enriched hydrogels could be formed, and subsequent addition of toluene then led to a phase-transfer of both the gelator and gold NPs to the organic solvent to yield organogels [64]. Recently, Fmoc-dipeptide gelators were used to achieve morphological control over gold NP growth (Figure 3); in 
particular, Fmoc-Phe-Tyr acted as strong reductant, leading to rectangularly shaped gold NPs, while Fmoc-Phe-Ser acted as mild reductant leading to spherical gold NPs [65].

Table 1. Metal NP formation templated by peptide gelators. n.d. = not determined

\begin{tabular}{|c|c|c|c|c|c|}
\hline Peptide Gelator & Metal & Solvent & Morphology & Size & Ref. \\
\hline Ac-Leu-Ile-Val-Ala-Gly-Lys- $\mathrm{NH}_{2}$ & $\mathrm{Ag}$ & Water & Spherical & $10-20 \mathrm{~nm}$ & [41] \\
\hline Boc-Tyr-Phe-Tyr-OMe & $\mathrm{Ag}$ & Methanol/Water & n.d. & $2-10 \mathrm{~nm}$ & [60] \\
\hline Cbz-Val-Val-Val-OMe & $\mathrm{Ag}$ & Butanol & Varied & $>100 \mathrm{~nm}$ & [61] \\
\hline Cbz-Val-Val-Cys(S-Bzl)-OMe & $\mathrm{Ag}$ & Butanol & Spherical & $9 \mathrm{~nm}$ & [61] \\
\hline Fmoc-Gly-Cys-Glu-OH & $\mathrm{Ag}$ & Water & n.d. & $1-2 \mathrm{~nm}$ & [46] \\
\hline Fmoc-Val-Asp-OH & $\mathrm{Ag}$ & DMSO/Water & n.d. & $1-3 \mathrm{~nm}$ & [40] \\
\hline (N-lythocholyl)-Gly-D-Phe & $\mathrm{Ag}$ & Water & spherical & $5-10,25 \mathrm{~nm}$ & {$[42]$} \\
\hline $\mathrm{N}, \mathrm{N}, \mathrm{N}$-trymethyl-Trp-NH- $\mathrm{C}_{16} \mathrm{H}_{33}$ & $\mathrm{Ag}$ & Water & Irregular & $10-20 \mathrm{~nm}$ & [62] \\
\hline Phe-Phe & $\mathrm{Ag}$ & Water & Nanowires & n.d. & [63] \\
\hline Boc-Phe-Tyr-Phe-OMe & $\mathrm{Au}$ & Toluene & n.d. & $50-80 \mathrm{~nm}$ & {$[60]$} \\
\hline Boc-Tyr-Phe-Tyr-OMe & $\mathrm{Au}$ & Toluene & n.d. & $15-20 \mathrm{~nm}$ & [60] \\
\hline Boc-Tyr-Phe-Tyr-OMe & $\mathrm{Au}$ & Methanol/Water & $\begin{array}{l}\text { Spherical/ } \\
\text { Hexagonal }\end{array}$ & $15-40 \mathrm{~nm}$ & {$[60]$} \\
\hline $\mathrm{C}_{15} \mathrm{H}_{31}$-CO-Val-Trp-OH & $\mathrm{Au}$ & Water or Toluene & Spherical & $12-14 \mathrm{~nm}$ & [64] \\
\hline $\mathrm{C}_{15} \mathrm{H}_{31}$-CO-Ile-Trp-OH & $\mathrm{Au}$ & Water or Toluene & Spherical & $12-14 \mathrm{~nm}$ & [64] \\
\hline $\mathrm{C}_{15} \mathrm{H}_{31}$-CO-Val-(N'-Me)-Trp-OH & $\mathrm{Au}$ & Water or Toluene & Spherical & $15-17 \mathrm{~nm}$ & [64] \\
\hline $\mathrm{C}_{15} \mathrm{H}_{31}-\mathrm{CO}-$ Val-Phe-OH & $\mathrm{Au}$ & Water or Toluene & Spherical & $15-17 \mathrm{~nm}$ & {$[64]$} \\
\hline Fmoc-Phe-Ser & $\mathrm{Au}$ & Water & Spherical & $7-9 \mathrm{~nm}$ & [65] \\
\hline Fmoc-Phe-Tyr & $\mathrm{Au}$ & Water & Rectangular & $\sim 140 \mathrm{~nm}$ & [65] \\
\hline $\mathrm{N}, \mathrm{N}, \mathrm{N}$-Trimethyl-Phe-NH- $\mathrm{C}_{16} \mathrm{H}_{33}$ & $\mathrm{Au}$ & Water & n.d. & $5-10 \mathrm{~nm}$ & [66] \\
\hline $\mathrm{N}, \mathrm{N}, \mathrm{N}$-Trimethyl-Phe-NH- $\mathrm{C}_{16} \mathrm{H}_{33}-\mathrm{NH}$-(N-Boc)-Phe & $\mathrm{Au}$ & Water & Octahedral & $15-30 \mathrm{~nm}$ & [66] \\
\hline $\begin{array}{l}N, N, N \text {-Trimethyl-Phe-NH- }{ }_{16} \mathrm{H}_{33}-\mathrm{NH}-\mathrm{Phe}-(\mathrm{N}- \\
\text { Boc)-Phe }\end{array}$ & $\mathrm{Au}$ & Water & $\begin{array}{l}\text { Octahedral/ } \\
\text { Irregular }\end{array}$ & $25-45 \mathrm{~nm}$ & [66] \\
\hline $\begin{array}{c}\mathrm{N}, \mathrm{N}, \mathrm{N} \text {-Trimethyl-Phe-NH- } \mathrm{C}_{16} \mathrm{H}_{33} \text {-NH-Ala-(N- } \\
\text { Boc)-Phe }\end{array}$ & $\mathrm{Au}$ & Water & $\begin{array}{l}\text { Octahedral/ } \\
\text { Irregular }\end{array}$ & $25-45 \mathrm{~nm}$ & [66] \\
\hline $\mathrm{N}, \mathrm{N}, \mathrm{N}$-Trimethyl-Trp-Pro-NH- $\mathrm{C}_{16} \mathrm{H}_{33}$ & $\mathrm{Au}$ & Water & 2D-Triangular & 1 micron & [58] \\
\hline N,N-Dimethyl-Pro-Trp-NH- $\mathrm{C}_{16} \mathrm{H}_{33}$ & $\mathrm{Au}$ & Water & Nanowires & $10 \mathrm{~nm}$ & [58] \\
\hline $\mathrm{N}, \mathrm{N}, \mathrm{N}$-Trimethyl-Trp-Phe-NH- $\mathrm{C}_{16} \mathrm{H}_{33}$ & $\mathrm{Au}$ & Water & Octahedral & $60 \mathrm{~nm}$ & [58] \\
\hline $\mathrm{N}, \mathrm{N}, \mathrm{N}$-Trimethyl-Phe-Trp-NH- ${ }_{16} \mathrm{H}_{33}$ & $\mathrm{Au}$ & Water & Decahedral & $210 \mathrm{~nm}$ & [58] \\
\hline Boc-Phe-Val-Phe-OH & $\mathrm{Cd}$ & Water & n.d. & $6-14 \mathrm{~nm}$ & [59] \\
\hline Boc-Phe-Leu-Phe-OH & $\mathrm{Cd}$ & Water & n.d. & $6-14 \mathrm{~nm}$ & [59] \\
\hline Boc-Phe-Phe-Phe-OH & $\mathrm{Cd}$ & Water & n.d. & $6-14 \mathrm{~nm}$ & [59] \\
\hline $\mathrm{C}_{15} \mathrm{H}_{31}-\mathrm{CO}-(\mathrm{Cys})_{4}-(\mathrm{Gly})_{3}-\mathrm{Sep}-\mathrm{Arg}-\mathrm{Gly}-\mathrm{Asp}-\mathrm{OH}$ & $\mathrm{Cd}$ & Water & Spherical & $3-7 \mathrm{~nm}$ & [67] \\
\hline HO-Tyr-Trp-Suc-Trp-Tyr-OH & $\mathrm{Pd}$ & Water & Spherical & $3-9 \mathrm{~nm}$ & [68] \\
\hline HO-Tyr-Leu-Suc-Phe-Tyr-OH & $\mathrm{Pt}$ & Water & Spherical & $1-6 \mathrm{~nm}$ & [69] \\
\hline$N, N^{\prime}, N^{\prime \prime}$-tri-((N-Boc)-Phe)-1,3,5-benzenetriamine & $\mathrm{Tm} / \mathrm{Yb}$ & Toluene & Spherical & $10-30 \mathrm{~nm}$ & [70] \\
\hline
\end{tabular}




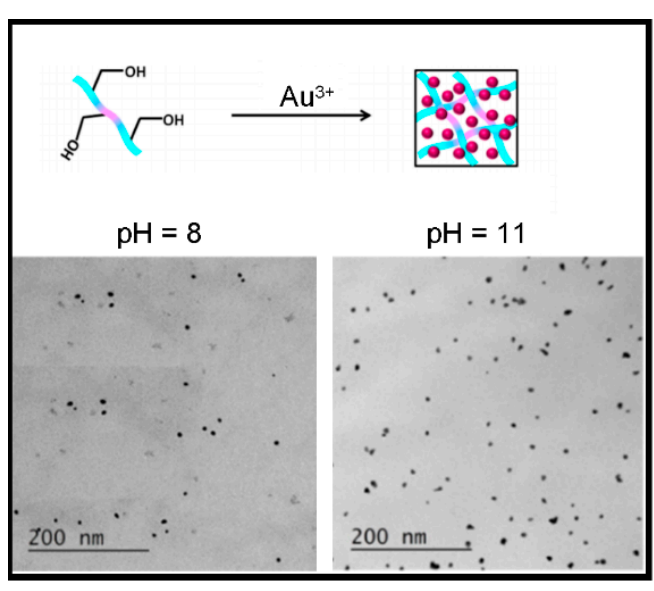

(a)

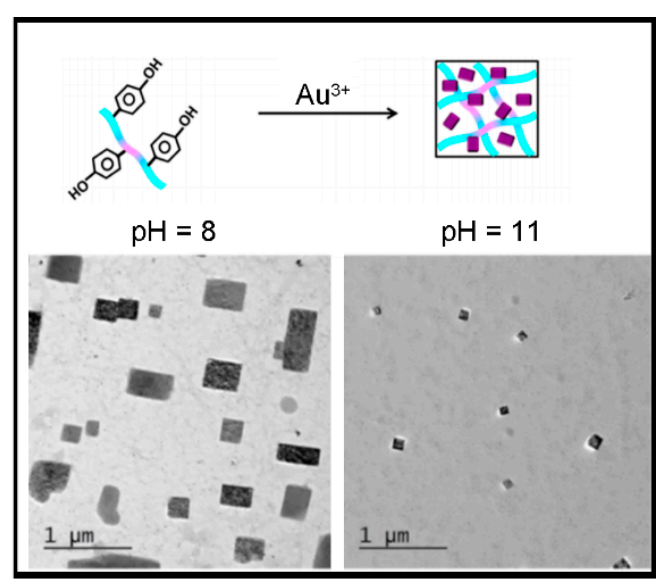

(b)

Figure 3. Self-assembling Fmoc-dipeptides template gold NPs with control over shape and size. (a) Fmoc-Phe-Ser yields spherical NPs. (b) Fmoc-Phe-Tyr yields rectangular plates. Adapted with permission from [65]. Copyright @ 2021, American Chemical Society.

\subsubsection{Silver (Ag)}

Silver NPs have been long-known for their good biocompatibility and antimicrobial activity, which find applications in the biomedical field [76], often combined with gels [77]. However, silver NPs are also attractive as conducting inks for use in electronics [78], and recently they are being re-discovered also as catalysts in a wide variety of organic transformations for the synthesis of fine chemicals [79]. Clearly, the development of green routes for their synthesis has become a key area of investigation [80].

The same gelators described above for the production of gold NPs [58] failed to produce silver NPs because of the undesired precipitation of $\mathrm{AgCl}$ due to the presence of chloride as the gelator counterion. A simple substitution towards aromatic carboxylate as counterions improved, at once, both the gelling ability of the peptide amphiphiles as well as their ability to template silver NPs, albeit with irregular shape [62].

In a different approach, silver photoreduction has been widely applied to obtain NPs templated by peptide gelators. For instance, a dipeptide with $\mathrm{COOH}$ groups as metal ligands was shown to promote sunlight-driven photoreduction of silver to form ultrasmall inorganic nanoparticles (1-3 nm diameter) embedded in a DMSO/water gel for envisaged applications as antimicrobial material [40]. Additionally a hexapeptide was used for the in situ UV-driven formation of 10-20 nm silver NPs, and the composite material showed antibacterial activity and good biocompatibility in vitro, as it was envisaged for wound healing applications [41]. Silver photoreduction was also successfully achieved for a bile acid-dipeptide conjugate; interestingly, the heterochiral dipeptide was effective for the purpose, while in the case of its diastereoisomer, photoreduction was not productive to form the silver NPs with antimicrobial activity [42].

Different was the case of a simple Fmoc-tripeptide with a Cys and Glu residues to provide coordinating ligands for $\mathrm{Ag}^{+}$that gelled only in the presence of silver ions (shown in Figure 1), and at the same time, the assembling process templated silver NP formation on the peptide nanofibers [46]. The role of $\mathrm{Ag}^{+}$in the gelation was confirmed by the addition of competing ligands, such as melamine or pyridine, which disrupted the gel that reformed upon addition of silver nitrate [46]. The hydrogel with silver NPs was effectively used for the degradation of methyl orange dye, and it also demonstrated antibacterial activity [46].

Stupp and co-workers also showed the reduction of silver using the Tollen's solution in contact with a peptide amphiphile hydrogelator, which led to the deposition of silver NPs onto the nanofibers (Figure 4), yielding hydrogels with antibacterial properties [81]. 
a)
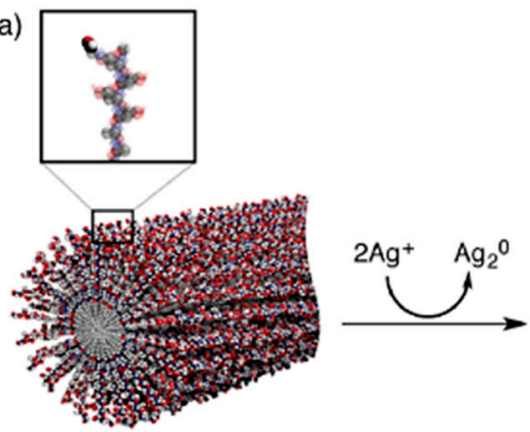

b)
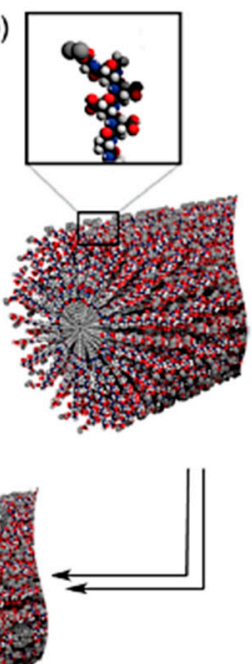

c)
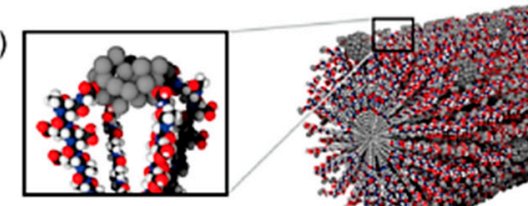

d)

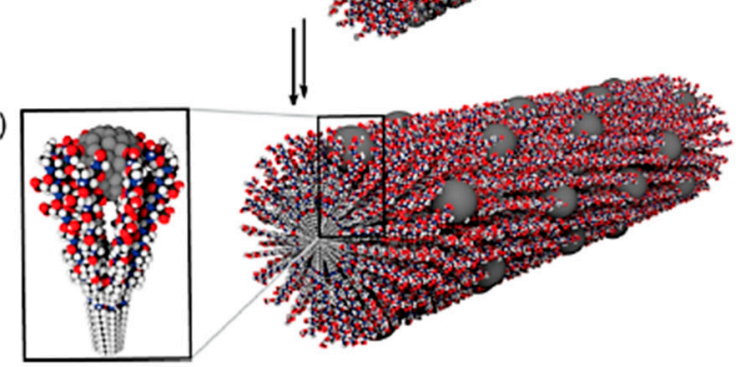

Figure 4. (a) Peptide amphiphile nanofiber with aldehyde groups on the surface. (b) Formation of silver clusters onto the nanofiber surface upon addition of the Tollen's reagent. (c) Silver nanoclusters are stabilized by the Glu carboxylic cid residues. (d) Silver nanoclusters fuse into Ag NPs anchored onto the peptide amphiphile's nanofiber surface. Reprinted with permission from [81]. Copyright $\odot$ 2021, American Chemical Society.

Furthermore, Cys(S-Bzl) thioether moieties were shown to direct the formation of silver NPs with spherical morphology and a diameter of $9 \mathrm{~nm}$, while analogous peptides without the Cys moieties led to larger NPs due to the lack of control over NP formation, which was driven mainly by the peptide hydrophobic environment [61]. This study confirmed once more the importance of including suitable metal ligands in the peptide sequence to attain fine control over the size and morphology of the resulting NPs.

\subsubsection{Cadmium Sulfide (CdS)}

Cadmium and, in particular, cadmium sulfide (CdS) have emerged as interesting nanomaterials for use in electronics [82]. In more recent applications, CdS NPs have also been combined with other metals, such as gold, for advanced performance in sensing, specifically for the detection of $\mathrm{Cu}^{2+}$ ions [83]. Stupp and co-workers developed peptide amphiphiles that could self-assemble into gelling fibers, whereby phosphoserine or the acidic groups effectively bound $\mathrm{Cd}^{2+}$ thus leading to the formation, upon addition of hyrogen disulfide, of 3-5 nm-wide CdS NPs onto the fibers' surface [67].

\subsubsection{Platinum (Pt)}

Pt NPs have been widely exploited by industry for their catalytic applications, such as their use in automotive converters as well as in petrochemical cracking [84], and supported platinum is also very useful in electrocatalysis for fuel cells and $\mathrm{CO}_{2}$ conversion [85]. More recently, Pt NPs also gained attention in the biomedical field, and for a range of uses that are based on their antimicrobial, antioxidant, and anticancer properties [86]. Research has also been active on their green synthesis [87]. One example was found in the literature that used a bolamphiphile, i.e., HO-Tyr-Leu-Suc-Phe-Tyr-OH, as a hydrogelator for the in situ 
formation of Pt NPs that were then applied for the hydrogenation in water of p-nitroaniline to p-phenylendiamine [69].

\subsubsection{Palladium $(\mathrm{Pd})$}

Pd-based nanostructures have also been widely studied for various applications in catalysis, and the topic has been reviewed in detail [88]. Similarly to the case of platinum, $\mathrm{Pd}$ NPs have also been re-discovered in the biomedical field, for applications that are rather diverse as they range from antimicrobial use to cancer therapy and sensing [89]. A similar bolamphiphile to the one mentioned above for platinum NPs, i.e., HO-Try-Trp-Suc-Trp-Tyr$\mathrm{OH}$ was reported as a sonication-induced hydrogelator that templated the in situ formation of Pd NPs which were used as catalysts for the N-deprotection of amino acids and peptides in the presence of sodium borohydride [68].

Keratin is among the cheapest and most widely available natural sources of proteinaceous materials, and is a promising resource to achieve hydrogels [90]. An interesting study used pre-treated human hair to adsorb $\mathrm{Pd}^{2+}$ and reduce it to $4 \mathrm{~nm}$-sized NPs through pyrolysis, for the heterogeneous catalytic reduction of nitrobenzene to aniline, which is an industrially-relevant target, being a precursor for a variety of pharmaceuticals, dyes, agricultural products, and polyurethanes [91]. The authors inferred that presence of Cys thiols, as well as other functional groups, in keratin may have promoted NP formation through metal coordination [91]. Therefore we anticipate similar applications also for keratin-derived gels.

\subsubsection{Lanthanides}

Lanthanide-doped upconverting NPs are able to convert near-infrared excitation into visible and ultraviolet emission. These unique properties find applications in disparate fields that include bioimaging, nanomedicine, and security labeling [92]. A tripodal Phe derivative showed the ability to gel a variety of organic solvents only upon application of ultrasounds; organogels in toluene were successfully used for the in situ formation of tamarium/ytterbium $(\mathrm{Tm} / \mathrm{Yb}) \mathrm{NPs}$ that decorated the surface of the gelling fibers and displayed interesting optical properties that the authors envisaged for the future development of optoelectronic devices [70].

\subsection{Nanotubes, Nanowires and Nanorods \\ 2.2.1. Gold}

Gold anisotropic nanostructures find important applications that encompass catalysis, sensing, and biomedicine, and their chemical synthesis has been recently reviewed [93]. There is an increasing interest towards the development of differently-shaped gold NPs and how morphology can be used to tune the properties of the final materials [94]. In particular, new methods are continuously sought for the controlled preparation of ultrathin gold nanowires [95], and gold nanorods [96]. A peptide amphiphile gelator was shown to self-assemble into helical nanoribbons and, upon addition of suitable reagents, including a gold salt and a reductant, in situ formation of gold nanorods associated to the outer surface of the nanoribbon was observed, as shown in Figure 5 [97]. Remarkably, the nanorods further associated into a helical superstructure along the ribbon and the authors proposed a mechanism through binding onto the aromatic surfaces of Phe and Tyr side chains, as well as Met functional groups [97]. 
a

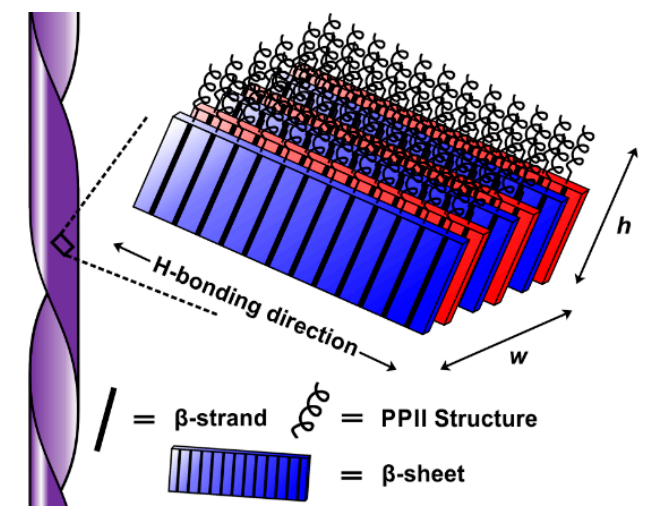

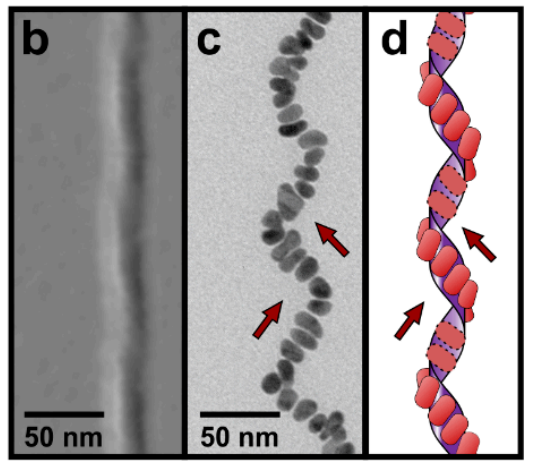

Figure 5. (a) Peptide amphiphile assembly model into a nanoribbon. (b) AFM image of the resulting assembled fiber. (c) TEM image of the gold nanorods oriented (arrows) into a helical pattern. (d) Proposed model of the gold nanorods associated to the outer surface of the peptide ribbon. Adapted with permission from [97]. Copyright (C) 2021, American Chemical Society.

\subsubsection{Silver}

Silver nanowires have recently gathered attention for their low cost, high conductivity, transmittance, and availability for applications in flexible electronics [98]. The first example of a supramolecular peptide nanostructure templating their formation goes back to 2003 [63]. Diphenylalanine was then described for its ability to self-assemble into nanotubes, whose hollow nature was exploited for the in situ formation of silver nanowires with the use of a reductant [63]. The peptide could easily be degraded by a hydrolytic enzyme to leave behind the metal nanowires [63]. It was later shown that this dipeptide forms metastable hydrogels $[99,100]$. Interestingly, while homochiral Phe-Phe is notorious for its uncontrolled hierarchical aggregation into nano- and microtubes, its heterochiral D-Phe-L-Phe isomer self-organizes into $4 \mathrm{~nm}$-wide nanotubes [101] that yield a hydrogel and could offer a way to achieve controlled-size and ultrathin metal nanowires.

\subsubsection{Silica}

Anisotropic silica nanostructures are promising candidates for advanced applications in the biomedical field, including biocatalysis, biosensing and drug release [102]. In particular, templated-assisted one-dimensional silica nanotubes have been attracting a great deal of interest [102]. We could not find examples in the literature of hybrid or composite gels whereby a peptide was used to template silica nanotubes, however, there are a few examples of peptide nanofibers doing the same in a sol-gel process. In particular, nanotube-forming octapeptide lanreotide was successfully used to template the formation of silica double-walled nanotubes [103]. Cationic peptides are expected to interact well with negatively-charged silicate anions. As an example, Arg-bearing fibrils from an 11 mer peptide templated hollow silica nanotubes more efficiently than an anionic analog [104]. Also Lys can be used to the same end [105], as demonstrated for the fibrillating Ile-Ile-IleLys [106] and Ac-Ile-Ile-Ile-Lys- $\mathrm{NH}_{2}$, which, combined with 3-aminopropyltriethoxysilane (APTES) and tetraethyl orthosilicate (TEOS) led to the templating of either bead-strings or uniform nanotubes in a sol-gel process [107]. Interestingly, however, also the anionic peptide Ac-Ile-Ile-Ile-Glu- $\mathrm{NH}_{2}$ was successful for the same purpose and adjustment of reaction conditions allowed the control over the hollow silica nanotube diameter from 10 to $60 \mathrm{~nm}$, as shown in Figure 6 [108]. 


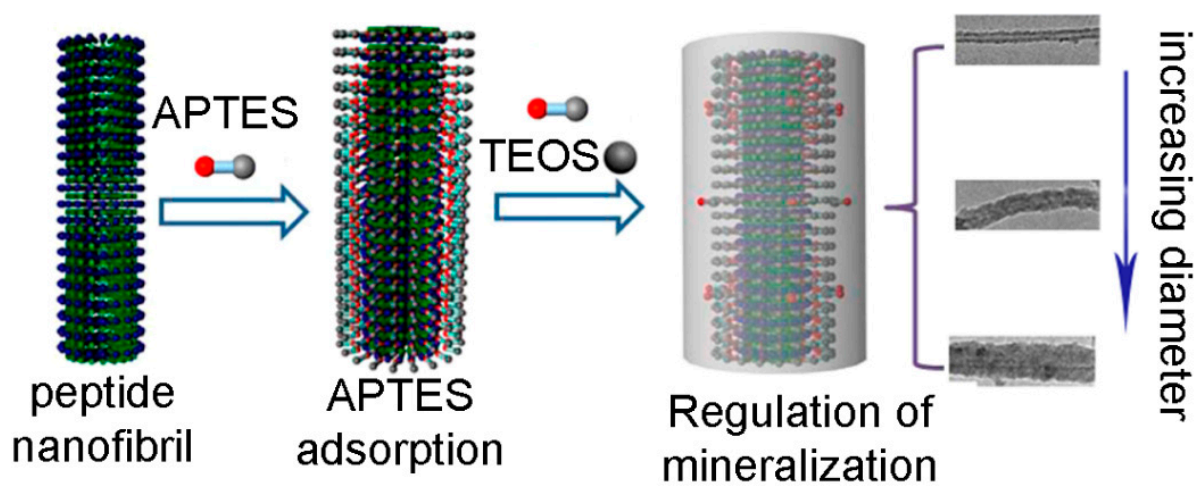

Figure 6. Silica nanotube formation on a peptide nanofibril through the adsorption of APTES and TEOS as precursors. Adapted with permission from [108]. Copyright (C) 2021, American Chemical Society.

\section{Conclusions}

This mini review highlighted the growing literature on the application of peptidebased gelators to template the in situ formation of metal nanostructures for a variety of applications. This field brings together the tunable properties of gels as well as their attractive feature of controlled embedment and release of guests, with those of inorganic nanoparticles. Not only does this approach provide green and economical ways to prepare innovative nanostructured materials, but also, finds applications in a variety of areas, ranging from biomedicine and sensing to catalysis and environmental detoxification, and so on [109]. Although the field has matured over the years, there is still a lack of understanding of many aspects. There are nonclassical phenomena that are unique to the nanoscale that are worth investigating, for instance with regards to unclear mechanisms of NP nucleation and growth that still need elucidation [110]. Understanding these aspects will provide the basis for a systematic approach towards the development of nanostructured materials for improved performance.

The field of nanomedicine is advancing at rapid pace. NP incorporation into nanogels holds promise in innovative therapy and targeted delivery for reduced side-effects [11,111]. Alternatively, multiple components can be combined together, as recently demonstrated in the case of a PEG hydrogel with gold nanorods, liposomes, and an antimicrobial peptide for the photo-triggered release of the latter [112]. Furthermore, metal coordination can also affect the properties of peptide-based supramolecular hydrogels in ways that are not always straightforward to predict, and further understanding in this area will be important [113]. In conclusion, as we gather further knowledge on the use of supramolecular chemistry based on peptides and green solvents for the templating of metal nanoparticles, we pave the way towards the development of advanced multi-component nanostructured materials for revolutionary applications that will certainly have an impact on society.

Author Contributions: Supervision, S.P., P.F. and S.M.; writing-original draft preparation, O.B. and M.C.C.; writing-review and editing, S.P., P.F., and S.M. All authors have read and agreed to the published version of the manuscript.

Funding: This research was funded by EU H2020 NMBP-SPIRE project, grant No. 820723.

Acknowledgments: The authors acknowledge M. Bisiacchi for her kind technical support.

Conflicts of Interest: The authors declare no conflict of interest.

\section{References}

1. De Santis, E.; Ryadnov, M.G. Peptide self-assembly for nanomaterials: The old new kid on the block. Chem. Soc. Rev. 2015, 44, 8288-8300. [CrossRef] [PubMed]

2. Jaradat, D.M.M. Thirteen decades of peptide synthesis: Key developments in solid phase peptide synthesis and amide bond formation utilized in peptide ligation. Amino Acids 2018, 50, 39-68. [CrossRef] [PubMed] 
3. Ding, Y.; Ting, J.P.; Liu, J.; Al-Azzam, S.; Pandya, P.; Afshar, S. Impact of non-proteinogenic amino acids in the discovery and development of peptide therapeutics. Amino Acids 2020, 52, 1207-1226. [CrossRef] [PubMed]

4. Brittain, W.D.; Lloyd, C.M.; Cobb, S.L. Synthesis of complex unnatural fluorine-containing amino acids. J. Fluor. Chem. 2020, 239, 109630. [CrossRef]

5. Hamley, I.W. Small Bioactive Peptides for Biomaterials Design and Therapeutics. Chem. Rev. 2017, 117, 14015-14041. [CrossRef]

6. Kurbasic, M.; Parisi, E.; Garcia, A.M.; Marchesan, S. Self-Assembling, Ultrashort Peptide Gels as Antimicrobial Biomaterials. Curr. Top. Med. Chem. 2020, 20, 1300-1309. [CrossRef]

7. Mondal, S.; Das, S.; Nandi, A.K. A review on recent advances in polymer and peptide hydrogels. Soft Matter 2020, 16, 1404-1454. [CrossRef]

8. Mikhalevich, V.; Craciun, I.; Kyropoulou, M.; Palivan, C.G.; Meier, W.P. Amphiphilic Peptide Self-Assembly: Expansion to Hybrid Materials. Biomacromolecules 2017, 18, 3471-3480. [CrossRef]

9. Cai, C.; Lin, J.; Lu, Y.; Zhang, Q.; Wang, L. Polypeptide self-assemblies: Nanostructures and bioapplications. Chem. Soc. Rev. 2016, 45, 5985-6012. [CrossRef]

10. Dånmark, S.; Aronsson, C.; Aili, D. Tailoring Supramolecular Peptide-Poly(ethylene glycol) Hydrogels by Coiled Coil SelfAssembly and Self-Sorting. Biomacromolecules 2016, 17, 2260-2267. [CrossRef]

11. Zhao, N.; Yan, L.; Zhao, X.; Chen, X.; Li, A.; Zheng, D.; Zhou, X.; Dai, X.; Xu, F. Versatile Types of Organic/Inorganic Nanohybrids: From Strategic Design to Biomedical Applications. Chem. Rev. 2019, 119, 1666-1762. [CrossRef] [PubMed]

12. Abul-Haija, Y.M.; Ulijn, R.V. Sequence Adaptive Peptide-Polysaccharide Nanostructures by Biocatalytic Self-Assembly. Biomacromolecules 2015, 16, 3473-3479. [CrossRef] [PubMed]

13. Ulijn, R.V. Best of both worlds. Nat. Nanotechnol. 2015, 10, 295-296. [CrossRef] [PubMed]

14. Iglesias, D.; Bosi, S.; Melchionna, M.; Da Ros, T.; Marchesan, S. The Glitter of Carbon Nanostructures in Hybrid/Composite Hydrogels for Medicinal Use. Curr. Top. Med. Chem. 2016, 16, 1976-1989. [CrossRef] [PubMed]

15. Li, J.; Li, X.; Xu, J.; Wang, Y.; Wu, L.; Wang, Y.; Wang, L.; Lee, M.; Li, W. Engineering the Ionic Self-Assembly of Polyoxometalates and Facial-Like Peptides. Chem. A Eur. J. 2016, 22, 15751-15759. [CrossRef]

16. Kieffer, M.; Garcia, A.M.; Haynes, C.J.E.; Kralj, S.; Iglesias, D.; Nitschke, J.R.; Marchesan, S. Embedding and Positioning of Two Fe II 4 L 4 Cages in Supramolecular Tripeptide Gels for Selective Chemical Segregation. Angew. Chem. Int. Ed. 2019, 58, 7982-7986. [CrossRef] [PubMed]

17. Čubová, K.; Čuba, V. Synthesis of inorganic nanoparticles by ionizing radiation-a review. Radiat. Phys. Chem. 2019, 158, 153-164. [CrossRef]

18. Darr, J.A.; Zhang, J.; Makwana, N.M.; Weng, X. Continuous Hydrothermal Synthesis of Inorganic Nanoparticles: Applications and Future Directions. Chem. Rev. 2017, 117, 11125-11238. [CrossRef]

19. Wolf, S.; Feldmann, C. Microemulsions: Options to Expand the Synthesis of Inorganic Nanoparticles. Angew. Chem. Int. Ed. 2016, 55, 15728-15752. [CrossRef]

20. Hao, N.; Nie, Y.; Zhang, J.X.J. Microfluidic synthesis of functional inorganic micro-/nanoparticles and applications in biomedical engineering. Int. Mater. Rev. 2018, 63, 461-487. [CrossRef]

21. Ziegler, C.; Wolf, A.; Liu, W.; Herrmann, A.-K.; Gaponik, N.; Eychmüller, A. Modern Inorganic Aerogels. Angew. Chem. Int. Ed. 2017, 56, 13200-13221. [CrossRef] [PubMed]

22. Giner-Casares, J.J.; Reguera, J. Directed self-assembly of inorganic nanoparticles at air/liquid interfaces. Nanoscale 2016, 8 , 16589-16595. [CrossRef] [PubMed]

23. Yi, C.; Yang, Y.; Liu, B.; He, J.; Nie, Z. Polymer-guided assembly of inorganic nanoparticles. Chem. Soc. Rev. 2020, 49, 465-508. [CrossRef] [PubMed]

24. Couto, A.R.S.; Ryzhakov, A.; Larsen, K.L.; Loftsson, T. Interaction of Native Cyclodextrins and Their Hydroxypropylated Derivatives with Carbamazepine in Aqueous Solution. Evaluation of Inclusion Complexes and Aggregates Formation. ACS Omega 2019, 4, 1460-1469. [CrossRef]

25. Li, D.; Qi, L. Self-assembly of inorganic nanoparticles mediated by host-guest interactions. Curr. Opin. Colloid Interface Sci. 2018, 35, 59-67. [CrossRef]

26. Heuer-Jungemann, A.; Feliu, N.; Bakaimi, I.; Hamaly, M.; Alkilany, A.; Chakraborty, I.; Masood, A.; Casula, M.F.; Kostopoulou, A.; Oh, E.; et al. The Role of Ligands in the Chemical Synthesis and Applications of Inorganic Nanoparticles. Chem. Rev. 2019, 119, 4819-4880. [CrossRef]

27. Elzoghby, A.O.; Hemasa, A.L.; Freag, M.S. Hybrid protein-inorganic nanoparticles: From tumor-targeted drug delivery to cancer imaging. J. Control. Release 2016, 243, 303-322. [CrossRef]

28. Sharma, V.K.; Filip, J.; Zboril, R.; Varma, R.S. Natural inorganic nanoparticles-formation, fate, and toxicity in the environment. Chem. Soc. Rev. 2015, 44, 8410-8423. [CrossRef]

29. Dahoumane, S.A.; Jeffryes, C.; Mechouet, M.; Agathos, S.N. Biosynthesis of Inorganic Nanoparticles: A Fresh Look at the Control of Shape, Size and Composition. Bioengineering 2017, 4, 14. [CrossRef]

30. Centi, G.; Perathoner, S. Creating and mastering nano-objects to design advanced catalytic materials. Coord. Chem. Rev. 2011, 255, 1480-1498. [CrossRef]

31. Heard, C.J.; Čejka, J.; Opanasenko, M.; Nachtigall, P.; Centi, G.; Perathoner, S. 2D Oxide Nanomaterials to Address the Energy Transition and Catalysis. Adv. Mater. 2018, 31, e1801712. [CrossRef] [PubMed] 
32. Liu, B.; Xie, J.; Lee, J.Y.; Ting, A.Y.P.; Chen, J.P. Optimization of High-Yield Biological Synthesis of Single-Crystalline Gold Nanoplates. J. Phys. Chem. B 2005, 109, 15256-15263. [CrossRef] [PubMed]

33. Kumar, S.; Natalio, F.; Elbaum, R. Protein-driven biomineralization: Comparing silica formation in grass silica cells to other biomineralization processes. J. Struct. Biol. 2021, 213, 107665. [CrossRef] [PubMed]

34. Chen, C.-L.; Rosi, N.L. Peptide-Based Methods for the Preparation of Nanostructured Inorganic Materials. Angew. Chem. Int. Ed. 2010, 49, 1924-1942. [CrossRef] [PubMed]

35. Durán, N.; Marcato, P.D.; Durán, M.; Yadav, A.; Gade, A.; Rai, M. Mechanistic aspects in the biogenic synthesis of extracellular metal nanoparticles by peptides, bacteria, fungi, and plants. Appl. Microbiol. Biotechnol. 2011, 90, 1609-1624. [CrossRef] [PubMed]

36. Gulsuner, H.U.; Ceylan, H.; Guler, M.O.; Tekinay, A.B. Multi-Domain Short Peptide Molecules for in Situ Synthesis and Biofunctionalization of Gold Nanoparticles for Integrin-Targeted Cell Uptake. ACS Appl. Mater. Interfaces 2015, 7, 10677-10683. [CrossRef]

37. Santos, S.A.O.; Pinto, R.J.; Rocha, S.M.; Marques, P.; Neto, C.P.; Silvestre, A.J.D.; Freire, C.S.R. Unveiling the Chemistry behind the Green Synthesis of Metal Nanoparticles. ChemSusChem 2014, 7, 2704-2711. [CrossRef]

38. El-Seedi, H.R.; El-Shabasy, R.M.; Khalifa, S.A.M.; Saeed, A.; Shah, A.; Shah, R.; Iftikhar, F.J.; Abdel-Daim, M.M.; Omri, A.; Hajrahand, N.H.; et al. Metal nanoparticles fabricated by green chemistry using natural extracts: Biosynthesis, mechanisms, and applications. RSC Adv. 2019, 9, 24539-24559. [CrossRef]

39. Nasaruddin, R.R.; Chen, T.; Yao, Q.; Zang, S.; Xie, J. Toward greener synthesis of gold nanomaterials: From biological to biomimetic synthesis. Coord. Chem. Rev. 2021, 426, 213540. [CrossRef]

40. Adhikari, B.; Banerjee, A. Short-Peptide-Based Hydrogel: A Template for the In Situ Synthesis of Fluorescent Silver Nanoclusters by Using Sunlight. Chem. A Eur. J. 2010, 16, 13698-13705. [CrossRef]

41. Reithofer, M.R.; Lakshmanan, A.; Ping, A.T.; Tan, T.T.Y.; Hauser, C.A.E. In situ synthesis of size-controlled, stable silver nanoparticles within ultrashort peptide hydrogels and their anti-bacterial properties. Biomaterials 2014, 35, 7535-7542. [CrossRef] [PubMed]

42. Maity, M.; Sajisha, V.S.; Maitra, U. Hydrogelation of bile acid-peptide conjugates and in situ synthesis of silver and gold nanoparticles in the hydrogel matrix. RSC Adv. 2015, 5, 90712-90719. [CrossRef]

43. Panigrahi, B.; Mishra, S.; Singh, R.K.; Siddiqui, N.; Bal, R.; Mandal, D. Peptide generated anisotropic gold nanoparticles as efficient siRNA vectors. Int. J. Pharm. 2019, 563, 198-207. [CrossRef]

44. Das, D.; Kar, T.; Das, P.K. Gel-nanocomposites: Materials with promising applications. Soft Matter 2012, 8, 2348-2365. [CrossRef]

45. Bhattacharya, S.; Samanta, S.K. Soft-Nanocomposites of Nanoparticles and Nanocarbons with Supramolecular and Polymer Gels and Their Applications. Chem. Rev. 2016, 116, 11967-12028. [CrossRef]

46. Hu, Y.; Xu, W.; Li, G.; Xu, L.; Song, A.; Hao, J. Self-Assembled Peptide Nanofibers Encapsulated with Superfine Silver Nanoparticles via Ag+ Coordination. Langmuir 2015, 31, 8599-8605. [CrossRef]

47. Kogan, M.J.; Olmedo, I.; Hosta, L.; Guerrero, A.R.; Cruz, L.J.; Albericio, F. Peptides and metallic nanoparticles for biomedical applications. Nanomedicine 2007, 2, 287-306. [CrossRef]

48. Halas, N.J. Nanoscience under Glass: The Versatile Chemistry of Silica Nanostructures. ACS Nano 2008, 2, 179-183. [CrossRef]

49. Bauer, L.A.; Birenbaum, N.S.; Meyer, G.J. Biological applications of high aspect ratio nanoparticles. J. Mater. Chem. 2004, 14, 517-526. [CrossRef]

50. Serban, B.A.; Barrett-Catton, E.; Serban, M.A. Tetraethyl Orthosilicate-Based Hydrogels for Drug Delivery-Effects of Their Nanoparticulate Structure on Release Properties. Gels 2020, 6, 38. [CrossRef]

51. Wang, Y.; Yang, X.; Liu, T.; Li, Z.; Leskauskas, D.; Liu, G.; Matson, J.B. Molecular-Level Control over Plasmonic Properties in Silver Nanoparticle/Self-Assembling Peptide Hybrids. J. Am. Chem. Soc. 2020, 142, 9158-9162. [CrossRef] [PubMed]

52. Roy, S.; Liu, Z.; Sun, X.; Gharib, M.; Yan, H.; Huang, Y.; Megahed, S.; Schnabel, M.; Zhu, D.; Feliu, N.; et al. Assembly and Degradation of Inorganic Nanoparticles in Biological Environments. Bioconjugate Chem. 2019, 30, 2751-2762. [CrossRef] [PubMed]

53. Naik, R.R.; Jones, S.E.; Murray, C.J.; McAuliffe, J.C.; Vaia, R.A.; Stone, M.O. Peptide Templates for Nanoparticle Synthesis Derived from Polymerase Chain Reaction-Driven Phage Display. Adv. Funct. Mater. 2004, 14, 25-30. [CrossRef]

54. Swami, A.; Kumar, A.; D'Costa, M.; Pasricha, R.; Sastry, M. Variation in morphology of gold nanoparticles synthesized by the spontaneous reduction of aqueous chloroaurate ions by alkylated tyrosine at a liquid-liquid and air-water interface. J. Mater. Chem. 2004, 14, 2696-2702. [CrossRef]

55. Yang, W.; Guo, W.; Changa, J.; Zhang, B. Protein/peptide-templated biomimetic synthesis of inorganic nanoparticles for biomedical applications. J. Mater. Chem. B 2016, 5, 401-417. [CrossRef] [PubMed]

56. Bai, Y.; Qin, B.; Zhou, Y.; Wang, Y.; Wang, Z.; Zheng, W. Preparation and antioxidant capacity of element selenium nanoparticles sol-gel compounds. J. Nanosci. Nanotechnol. 2011, 11, 5012-5017. [CrossRef]

57. Kim, H.; Bang, K.-M.; Ha, H.; Cho, N.H.; Namgung, S.D.; Im, S.W.; Cho, K.H.; Kim, R.M.; Choi, W.I.; Lim, Y.-C.; et al. Tyrosyltyrosylcysteine-Directed Synthesis of Chiral Cobalt Oxide Nanoparticles and Peptide Conformation Analysis. ACS Nano 2020. [CrossRef]

58. Mitra, R.N.; Das, P.K. In situ Preparation of Gold Nanoparticles of Varying Shape in Molecular Hydrogel of Peptide Amphiphiles. J. Phys. Chem. C 2008, 112, 8159-8166. [CrossRef]

59. Palui, G.; Nanda, J.; Ray, S.; Banerjee, A. Fabrication of Luminescent CdS Nanoparticles on Short-Peptide-Based Hydrogel Nanofibers: Tuning of Optoelectronic Properties. Chem. A Eur. J. 2009, 15, 6902-6909. [CrossRef] 
60. Ray, S.; Das, A.K.; Banerjee, A. Smart oligopeptide gels: In situ formation and stabilization of gold and silver nanoparticles within supramolecular organogel networks. Chem. Commun. 2006, 26, 2816-2818. [CrossRef]

61. Mantion, A.; Guex, A.G.; Foelske-Schmitz, A.; Mirolo, L.; Fromm, K.M.; Painsi, M.; Taubert, A.; Foelske-Schmitz, A. Silver nanoparticle engineering via oligovaline organogels. Soft Matter 2008, 4, 606-617. [CrossRef]

62. Dutta, S.; Shome, A.; Debnath, S.; Das, P.K. Counterion dependent hydrogelation of amino acid based amphiphiles: Switching from non-gelators to gelators and facile synthesis of silver nanoparticles. Soft Matter 2009, 5, 1607-1620. [CrossRef]

63. Reches, M. Casting Metal Nanowires Within Discrete Self-Assembled Peptide Nanotubes. Science 2003, 300, 625-627. [CrossRef] [PubMed]

64. Kar, T.; Dutta, S.; Das, P.K. pH-Triggered conversion of soft nanocomposites: In situ synthesized AuNP-hydrogel to AuNPorganogel. Soft Matter 2010, 6, 4777-4787. [CrossRef]

65. Jain, R.; Khandelwal, G.; Roy, S. Unraveling the Design Rules in Ultrashort Amyloid-Based Peptide Assemblies toward ShapeControlled Synthesis of Gold Nanoparticles. Langmuir 2019, 35, 5878-5889. [CrossRef] [PubMed]

66. Das, D.; Maiti, S.; Brahmachari, S.; Das, P.K. Refining hydrogelator design: Soft materials with improved gelation ability, biocompatibility and matrix for in situ synthesis of specific shaped GNP. Soft Matter 2011, 7, 7291-7303. [CrossRef]

67. Sone, E.D.; Stupp, S.I. Semiconductor-Encapsulated Peptide-Amphiphile Nanofibers. J. Am. Chem. Soc. 2004, 126, 12756-12757. [CrossRef] [PubMed]

68. Maity, I.; Manna, M.K.; Rasale, D.B.; Das, A.K. Peptide-Nanofiber-Supported Palladium Nanoparticles as an Efficient Catalyst for the Removal of N-Terminus Protecting Groups. ChemPlusChem 2014, 79, 413-420. [CrossRef]

69. Maity, I.; Rasale, D.B.; Das, A.K. Sonication induced peptide-appended bolaamphiphile hydrogels for in situ generation and catalytic activity of Pt nanoparticles. Soft Matter 2012, 8, 5301-5308. [CrossRef]

70. Maity, S.; Sarkar, S.; Jana, P.; Maity, S.K.; Bera, S.; Mahalingam, V.; Haldar, D. Sonication-responsive organogelation of a tripodal peptide and optical properties of embedded $\mathrm{Tm}^{3+}$ nanoclusters. Soft Matter 2012, 8, 7960-7966. [CrossRef]

71. Stratakis, M.; Garcia, H. Catalysis by Supported Gold Nanoparticles: Beyond Aerobic Oxidative Processes. Chem. Rev. 2012, 112, 4469-4506. [CrossRef]

72. Das, M.; Shim, K.H.; An, S.S.A.; Yi, D.K. Review on gold nanoparticles and their applications. Toxicol. Environ. Health Sci. 2011, 3, 193-205. [CrossRef]

73. Fan, M.; Han, Y.; Gao, S.; Yan, H.; Cao, L.; Li, Z.; Liang, X.-J.; Zhang, J. Ultrasmall gold nanoparticles in cancer diagnosis and therapy. Theranostics 2020, 10, 4944-4957. [CrossRef] [PubMed]

74. Norouzi, M. Gold Nanoparticles in Glioma Theranostics. Pharmacol. Res. 2020, 156, 104753. [CrossRef] [PubMed]

75. Zong, J.; Cobb, S.L.; Cameron, N.R. Peptide-functionalized gold nanoparticles: Versatile biomaterials for diagnostic and therapeutic applications. Biomater. Sci. 2017, 5, 872-886. [CrossRef]

76. Siddiqi, K.S.; Husen, A.; Rao, R.A.K. A review on biosynthesis of silver nanoparticles and their biocidal properties. J. Nanobiotechnol. 2018, 16, 1-28. [CrossRef]

77. Casolaro, M.; Casolaro, I.; Akimoto, J.; Ueda, M.; Ueki, M.; Ito, Y. Antibacterial Properties of Silver Nanoparticles Embedded on Polyelectrolyte Hydrogels Based on $\alpha$-Amino Acid Residues. Gels 2018, 4, 42. [CrossRef]

78. Yaqoob, A.A.; Umar, K.; Ibrahim, M.N.M. Silver nanoparticles: Various methods of synthesis, size affecting factors and their potential applications-A review. Appl. Nanosci. 2020, 10, 1369-1378. [CrossRef]

79. Dong, X.-Y.; Gao, Z.-W.; Yang, K.-F.; Zhang, W.; Xu, L.-W. Nanosilver as a new generation of silver catalysts in organic transformations for efficient synthesis of fine chemicals. Catal. Sci. Technol. 2015, 5, 2554-2574. [CrossRef]

80. Rauwel, P.; Küünal, S.; Ferdov, S.; Rauwel, E. A Review on the Green Synthesis of Silver Nanoparticles and Their Morphologies Studied via TEM. Adv. Mater. Sci. Eng. 2015, 2015, 1-9. [CrossRef]

81. Pazos, E.; Sleep, E.; Pérez, C.M.R.; Lee, S.S.; Tantakitti, F.; Stupp, S.I. Nucleation and Growth of Ordered Arrays of Silver Nanoparticles on Peptide Nanofibers: Hybrid Nanostructures with Antimicrobial Properties. J. Am. Chem. Soc. 2016, 138, 5507-5510. [CrossRef] [PubMed]

82. Hullavarad, N.V.; Hullavarad, S.S.; Karulkar, P.C. Cadmium Sulphide (CdS) Nanotechnology: Synthesis and Applications. J. Nanosci. Nanotechnol. 2008, 8, 3272-3299. [CrossRef] [PubMed]

83. Ibrahim, I.; Lim, H.; Abou-Zied, O.K.; Huang, N.M.; Estrela, P.; Pandikumar, A. Cadmium Sulfide Nanoparticles Decorated with Au Quantum Dots as Ultrasensitive Photoelectrochemical Sensor for Selective Detection of Copper(II) Ions. J. Phys. Chem. C 2016, 120, 22202-22214. [CrossRef]

84. Peng, Z.; Yang, H. Designer platinum nanoparticles: Control of shape, composition in alloy, nanostructure and electrocatalytic property. Nano Today 2009, 4, 143-164. [CrossRef]

85. Perathoner, S.; Gangeri, M.; Lanzafame, P.; Centi, G. Nanostructured electrocatalytic Pt-carbon materials for fuel cells and $\mathrm{CO}_{2}$ conversion. Kinet. Catal. 2007, 48, 877-883. [CrossRef]

86. Jeyaraj, M.; Gurunathan, S.; Qasim, M.; Kang, M.-H.; Kim, J.-H. A Comprehensive Review on the Synthesis, Characterization, and Biomedical Application of Platinum Nanoparticles. Nanomaterials 2019, 9, 1719. [CrossRef]

87. Jameel, M.S.; Aziz, A.A.; Dheyab, M.A. Green synthesis: Proposed mechanism and factors influencing the synthesis of platinum nanoparticles. Green Process. Synth. 2020, 9, 386-398. [CrossRef]

88. Chen, A.; Ostrom, C. Palladium-Based Nanomaterials: Synthesis and Electrochemical Applications. Chem. Rev. 2015, 115, 11999-12044. [CrossRef] 
89. Phan, T.T.V.; Huynh, T.-C.; Manivasagan, P.; Mondal, S.; Oh, J. An Up-To-Date Review on Biomedical Applications of Palladium Nanoparticles. Nanomaterials 2020, 10, 66. [CrossRef]

90. Richter, J.R.; De Guzman, R.C.; Greengauz-Roberts, O.K.; Van Dyke, M. Structure-property relationships of meta-kerateine biomaterials derived from human hair. Acta Biomater. 2012, 8, 274-281. [CrossRef]

91. Mendonça, F.; Silva, T.; Nascimento, G.D.; Stumpf, H.; Mambrini, R.; Pim, W.D.D. Human Hair as Adsorbent of Palladium(II) in Solution: A Precursor of Well-Dispersed Size-Controlled Pd Nanoparticles. J. Braz. Chem. Soc. 2018, 30, 736-743. [CrossRef]

92. Wen, S.; Zhou, J.; Zheng, K.; Bednarkiewicz, A.; Liu, X.; Jin, D. Advances in highly doped upconversion nanoparticles. Nat. Commun. 2018, 9, 2415. [CrossRef] [PubMed]

93. Ortiz-Castillo, J.E.; Gallo-Villanueva, R.C.; Madou, M.J.; Perez-Gonzalez, V.H. Anisotropic gold nanoparticles: A survey of recent synthetic methodologies. Coord. Chem. Rev. 2020, 425, 213489. [CrossRef]

94. Bandyopadhyay, S.; Sharma, A.; Glomm, W.R. The Influence of Differently Shaped Gold Nanoparticles Functionalized with NIPAM-Based Hydrogels on the Release of Cytochrome C. Gels 2017, 3, 42. [CrossRef]

95. Jiang, X.; Qiu, X.; Fuac, G.; Sun, J.; Huang, Z.; Sun, D.; Xu, L.; Zhou, J.-C.; Tang, Y.-W. Highly simple and rapid synthesis of ultrathin gold nanowires with (111)-dominant facets and enhanced electrocatalytic properties. J. Mater. Chem. A 2018, 6, 17682-17687. [CrossRef]

96. Meng, L.; Zhang, J.; Li, H.; Zhao, W.; Zhao, T. Preparation and Progress in Application of Gold Nanorods. J. Nanomater. 2019, 2019, 1-11. [CrossRef]

97. Merg, A.D.; Boatz, J.C.; Mandal, A.; Zhao, G.; Mokashi-Punekar, S.; Liu, C.; Wang, X.; Zhang, P.; Van Der Wel, P.C.A.; Rosi, N.L. Peptide-Directed Assembly of Single-Helical Gold Nanoparticle Superstructures Exhibiting Intense Chiroptical Activity. J. Am. Chem. Soc. 2016, 138, 13655-13663. [CrossRef]

98. Li, W.; Zhang, H.; Shi, S.; Xu, J.; Qin, X.; He, Q.; Yang, K.; Dai, W.; Liu, G.; Zhou, Q.; et al. Recent progress in silver nanowire networks for flexible organic electronics. J. Mater. Chem. C 2020, 8, 4636-4674. [CrossRef]

99. Conte, M.P.; Singh, N.; Sasselli, I.R.; Escuder, B.; Ulijn, R.V. Metastable hydrogels from aromatic dipeptides. Chem. Commun. 2016, 52, 13889-13892. [CrossRef]

100. Kurbasic, M.; Semeraro, S.; Garcia, A.M.; Kralj, S.; Parisi, E.; Deganutti, C.; De Zorzi, R.; Marchesan, S. Microwave-Assisted Cyclization of Unprotected Dipeptides in Water to 2,5-Piperazinediones and Self-Assembly Study of Products- and Reagents. Synthesis 2019, 51, 2829-2838. [CrossRef]

101. Kralj, S.; Bellotto, O.; Parisi, E.; Garcia, A.M.; Iglesias, D.; Semeraro, S.; Deganutti, C.; D’Andrea, P.; Vargiu, A.V.; Geremia, S.; et al. Heterochirality and Halogenation Control Phe-Phe Hierarchical Assembly. ACS Nano 2020, 14, 16951-16961. [CrossRef] [PubMed]

102. Yang, X.-F.; Tang, H.; Cao, K.; Song, H.; Sheng, W.; Wu, Q. Templated-assisted one-dimensional silica nanotubes: Synthesis and applications. J. Mater. Chem. 2011, 21, 6122-6135. [CrossRef]

103. Pouget, E.; Dujardin, E.; Cavalier, A.; Moreac, A.; Valéry, C.; Marchi-Artzner, V.; Weiss, T.; Renault, A.; Paternostre, M.; Artzner, F. Hierarchical architectures by synergy between dynamical template self-assembly and biomineralization. Nat. Mater. 2007, 6, 434-439. [CrossRef] [PubMed]

104. Meegan, J.E.; Aggeli, A.; Boden, N.; Brydson, R.; Brown, A.P.; Carrick, L.; Brough, A.R.; Hussain, A.; Ansell, R.J. Designed Self-Assembled $\beta$-Sheet Peptide Fibrils as Templates for Silica Nanotubes. Adv. Funct. Mater. 2004, 14, 31-37. [CrossRef]

105. Yuwono, V.M.; Hartgerink, J.D. Peptide Amphiphile Nanofibers Template and Catalyze Silica Nanotube Formation. Langmuir 2007, 23, 5033-5038. [CrossRef] [PubMed]

106. Wang, S.; Ge, X.; Xue, J.; Fan, H.; Mu, L.; Li, Y.; Xu, H.; Lu, J.R. Mechanistic Processes Underlying Biomimetic Synthesis of Silica Nanotubes from Self-Assembled Ultrashort Peptide Templates. Chem. Mater. 2011, 23, 2466-2474. [CrossRef]

107. Wang, S.; Xue, J.; Ge, X.; Fan, H.; Xu, H.; Lu, J.R. Biomimetic synthesis of silica nanostructures with controllable morphologies and sizes through tuning interfacial interactions. Chem. Commun. 2012, 48, 9415-9417. [CrossRef]

108. Wang, S.; Cai, Q.; Du, M.; Xue, J.; Xu, H. Synthesis of 1D Silica Nanostructures with Controllable Sizes Based on Short Anionic Peptide Self-Assembly. J. Phys. Chem. B 2015, 119, 12059-12065. [CrossRef]

109. Divya, K.P.; Miroshnikov, M.; Dutta, D.; Vemula, P.K.; Ajayan, P.M.; John, G. In Situ Synthesis of Metal Nanoparticle Embedded Hybrid Soft Nanomaterials. Acc. Chem. Res. 2016, 49, 1671-1680. [CrossRef]

110. Lee, J.; Yang, J.; Kwon, S.G.; Hyeon, T. Nonclassical nucleation and growth of inorganic nanoparticles. Nat. Rev. Mater. 2016, 1, 16034. [CrossRef]

111. Pinelli, F.; Perale, G.; Rossi, F. Coating and Functionalization Strategies for Nanogels and Nanoparticles for Selective Drug Delivery. Gels 2020, 6, 6. [CrossRef] [PubMed]

112. Moorcroft, S.C.T.; Roach, L.; Jayne, D.G.; Ong, Z.Y.; Evans, S.D. Nanoparticle-Loaded Hydrogel for the Light-Activated Release and Photothermal Enhancement of Antimicrobial Peptides. ACS Appl. Mater. Interfaces 2020, 12, 24544-24554. [CrossRef] [PubMed]

113. Shao, T.; Falcone, N.; Kraatz, H.B. Supramolecular Peptide Gels: Influencing Properties by Metal Ion Coordination and Their Wide-Ranging Applications. ACS Omega 2020, 5, 1312-1317. [CrossRef] [PubMed] 